\title{
APARTEMEN DENGAN PENDEKATAN DESAIN BIOPHILIK DI JAKARTA SELATAN
}

\author{
Aprilia Dewi Pramarti, Sri Yuliani, Kusumaningdyah NH \\ Program Studi Arsitektur \\ Universitas Sebelas Maret Surakarta \\ Email : adpramarti@yahoo.com
}

\begin{abstract}
In 2015, South Jakarta region was the most active in supplying office. This Development is certainly an impact on the growing needs of residential apartments as a provision of housing solution in the downtown. Conditions of Jakarta city with traffic congestion and insufficient green open space as a place of social interaction is one of the high levels stress triggers of Jakarta residents. Therefore, the provision of housing needed an apartment that is able to address issues regarding the provision of green open space, social housing activities system and space requirements that can provide therapeutic effects on the occupants in it as an effort to reduce stress levels. The approach method used in addressing the problem is Biophilic Design, where a building is able to harmony the interests of a human with nature. Purposes of applying the Biophilic Design into an apartment building is to create a shelter that can deliver restorative spaces for human physical, sanify nervous system and improve the prosperousity. Application of Biophilic Design into buildings accomplished by implementing 8 of 14 patterns of Biophilic Design which have been under consideration ease of implementation and the effects on the psychological stimulated. The determined patterns then synthesized with architectural elements and applied in the form of the mass of the building, lighting systems, air system, use of materials and green open space provision system vertically.
\end{abstract}

Keywords: Apartment, Biophilic Design, Green Open Space.

\section{PENDAHULUAN}

Pertumbuhan gedung perkantoran di Jakarta yang kian pesat menjadi magnet tersendiri bagi penduduk Indonesia untuk melakukan urbanisasi ke kota Jakarta. Pada tahun 2015, Kawasan Jakarta Selatan merupakan daerah yang paling aktif dalam memasok perkantoran. Kontribusi kawasan ini sebanyak sembilan dari 12 kantor yang diproyeksikan dibangun pada 2015.

Semakin banyaknya ruang perkantoran yang hadir maka semakin banyak pula lapangan pekerjaan yang akan menjadi sasaran dan tujuan untuk melakukan urbanisasi. Semakin tinggi tingkat urbanisasi maka semakin tinggi pula tingkat kepadatan penduduk di Kota Jakarta. Oleh sebab itu, kebutuhan sebuah hunian di tengah kota tentunya menjadi sebuah kebutuhan yang riil.

Kondisi kota Jakarta akibat kepadatan penduduk memberikan dampak terhadap kondisi lalu lintas maupun psikologis masyarakat dimana saat ini $14 \%$ warga
Jakarta mengalami stress akibat permasalah tersebut. Hunian yang dibutuhkan bagi warga Jakarta bukan lagi sekedar hunian yang menyediakan tempat tinggal namun yang mampu memberikan kenyamanan, ketenangan dan meningkatkan kesehatan jasmani maupun jiwa penghuni.

Salah satu jenis hunian yang telah banyak berkembang di Kota Jakarta adalah apartemen. Keberadaan apartemen di Jakarta jumlahnya cukup banyak, namun kondisi apartemen yang ada saat ini hanya sekedar memenuhi kebutuhan dasar akan sebuah tempat tinggal tanpa mempertimbangkan dampak terhadap hubungan sosial antar penghuni di dalamnya maupun hubungan antara manusia dengan alam.

Menanggapi hal tersebut, apartemen ini dirancang dengan penerapan desain biophilik ke dalam bangunan untuk menciptakan apartemen yang tidak hanya sekedar mampu memenuhi kebutuhan dasar akan tempat tinggal tapi mampu menyelaraskan 
kepentingan manusia dan alam dengan menghadirkan fasilitas ruang terbuka hijau ke dalam bangunan vertikal sebagai ruang sosial bagi penghuni.

Desain Biophilik adalah sebuah bangunan yang mampu menyelaraskan kepentingan alam dan manusia (Kellert, 2005). Tujuan penerapan Desain Biophilik ke dalam sebuah unit hunian yaitu untuk menciptakan sebuah tempat tinggal yang mampu menghadirkan ruang-ruang restoratif bagi fisik manusia, menyehatkan sistem syaraf, dan meningkatkan kesejahteraan (well-being).

\section{METODE}

Metode yang dilakukan dalam penyusunan konsep perencanaan dan perancangan adalah sebagai berikut.

A. Eksplorasi : menggali isu mengenai kondisi permasalahan hunian di Kota Jakarta melalui berita, wawancara singkat dan studi empirik.

B. Pengumpulan Data dan Informasi: Pengumpulan data, informasi dan teori mengenai apartemen, ruang terbuka hijau, Desain Biophilik dan tinjauan Jakarta Selatan menggunakan metode kegiatan studi literatur dan studi preseden.

C. Merujuk 14 pola Desain Biophilik (Browning dkk, 2014) yaitu koneksi visual terhadap alam, koneksi nonvisual terhadap alam, air, stimuli nonritmik, cahaya yang dinamis, thermal dan variasi aliran udara, bentuk dan patra biomorfik, koneksi antar sistem alami, koneksi material dengan alam, kompleksitas dan order, prospek, resiko, refuge, dan misteri. Berdasarkan pertimbangan terhadap kebutuhan apartemen dan efek dari penerapan pola maka diambil 8 pola Desain Biophilik yaitu koneksi visual terhadap alam, koneksi non-visual terhadap alam, air, cahaya yang dinamis, thermal dan variasi aliran udara, bentuk dan patra biomorfik, stimuli non-ritmik, koneksi material dengan alam.

D. Mensintesakan 8 pola Desain Biophilik yang terpilih dengan kebutuhan elemen arsitektural berupa fungsi ruang, eksisting tapak, bentuk massa, zonasi, akses terhadap alam, penyediaan RTH, dan kebutuhan ruang (lihat Gambar 1.).

E. Analisis perencanaan dilakukan dengan mengolah data yang telah terkumpul dan dikelompokkan berdasarkan pemrograman fungsional, dan pemograman performasi.

1. Pemrograman fungsional bertujuan untuk mengidentifikasi pengguna dan kegiatan.

2. Pemrograman performasi menghasilkan kriteria performansi antara lain identifikasi fasilitas yang akan disediakan, jumlah unit yang akan disediakan, dan penerapan pendekatan Desain Biophilik pada obyek.

D. Analisis arsitektural merupakan proses menerjemahkan program fungsional dan pernyataan performansi ke dalam spesifikasi rancangan performasi. Proses tersebut antara lain analisis kebutuhan ruang, analisis penerapan Desain Biophilik, analisis tapak, analisis bentuk, material, dan tampilan bangunan, serta analisis utilitas.

E. Transformasi konsep perencanaan dan perancangan ke dalam bentuk desain.

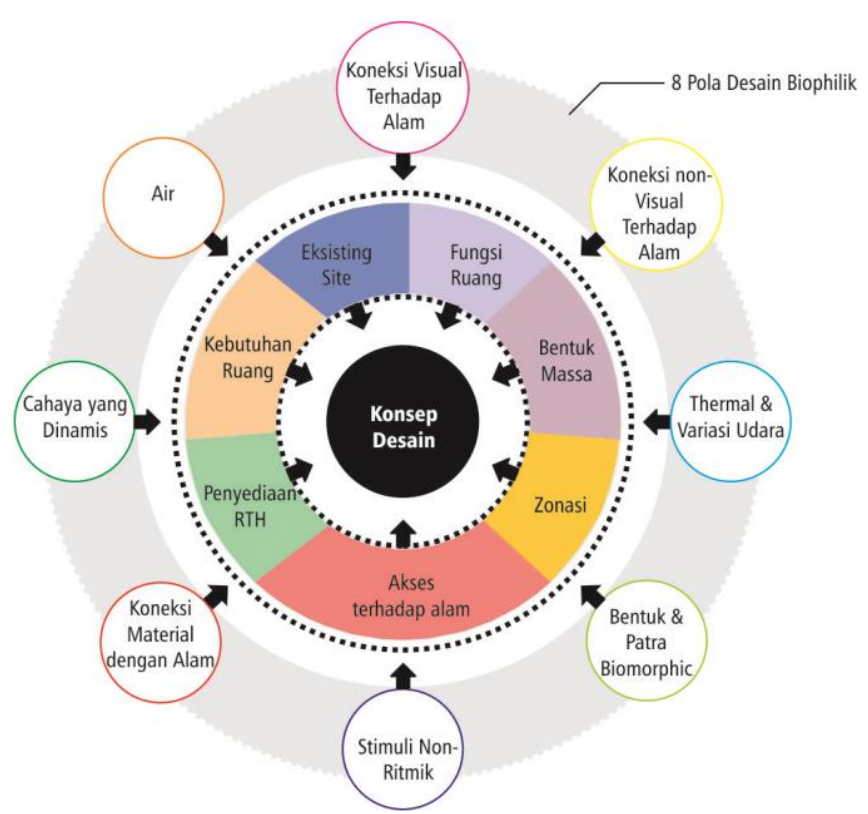

Gambar 1. Pola Pikir 


\section{ANALISIS}

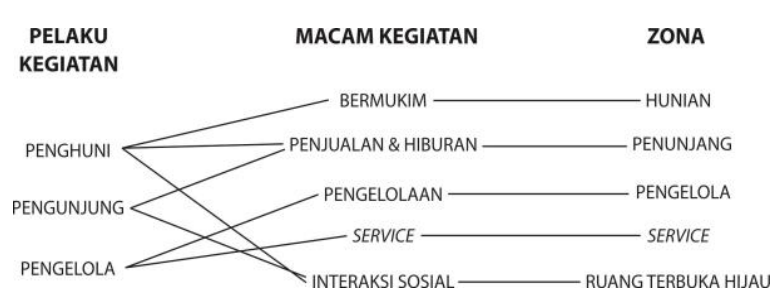

Gambar 2. Hubungan Pelaku, Macam Kegiatan dan Zona Ruang pada Apartemen

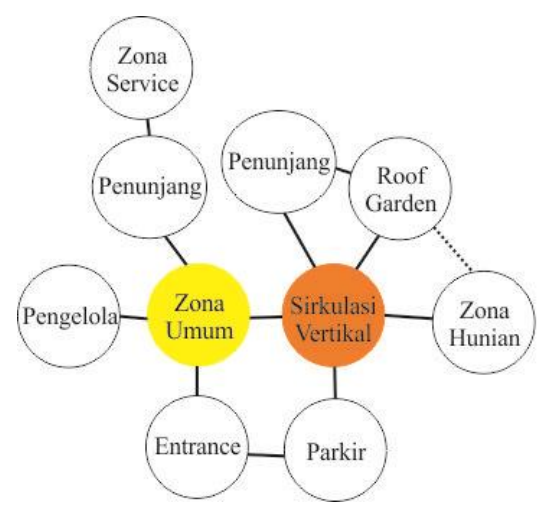

Gambar 3. Hubungan Ruang Antar Zona

\section{A. Analisis Ruang}

Kebutuhan ruang dan zonasi ruang berdasarkan pola dan pelaku kegiatan (lihat Gambar 2.). Berikut ini merupakan organisasi hubungan ruang antar zona (lihat Gambar 3.).

B. Analisis Lokasi

Menentukan lokasi yang strategis dan sesuai dengan kebutuhan apartemen.

1. Tujuan

Lokasi yang strategis dan sesuai dengan kebutuhan sebuah apartemen.

2. Dasar pertimbangan:

Posisi tapak strategis, sesuai dengan peruntukkan lahan, dekat dengan fasilitas kesehatan, pendidikan, hiburan, dan perbelanjaan, serta luasan tapak dapat menampung seluruh kebutuhan ruang yang direncanakan.

3. Lokasi terpilih: Jl. Lebak Bulus 1, Cilandak, Jakarta Selatan. (lihat Gambar 4.). Terdapat eksisting pepohonan.

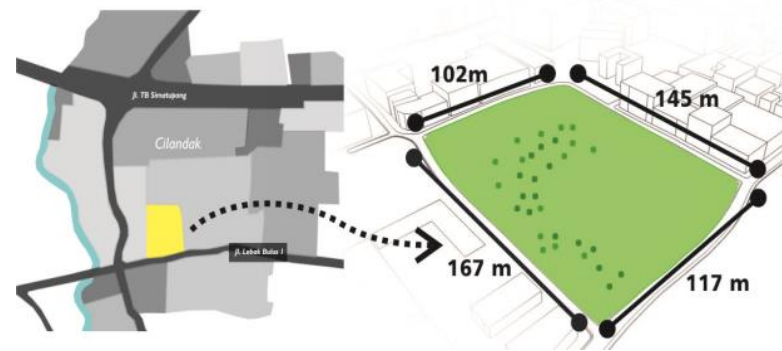

Gambar 4. Lokasi Tapak Terpilih

Sirkulasi

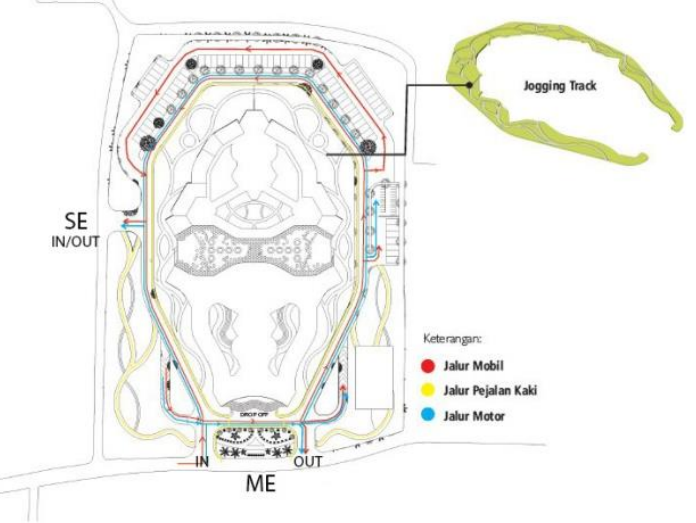

Gambar 5. Pola Pencapaian

C. Analisis Pencapaian

Pencapaian ke dalam apartemen harus mudah diakses, mudah dilihat dan memiliki sirkulasi yang aman.

1. Tujuan: main entrance, menentukan side entrance

2. Dasar pertimbangan: kemudahan akses, sirkulasi tapak yang aksesibel, arus kendaraan dan tingkat keamanan.

3. Proses analisis

a. Main Entrance (ME) Mudah dijangkau dan terlihat dengan jelas. Menghadap langsung ke arah jalan untuk kemudahan sirkulasi kendaraan masuk dan ke luar tapak.

b. Side Entrance (SE)

Tidak mengganggu keberadaan ME. Membantu sirkulasi pengunjung.

c. Sirkulasi kendaraan mengelilingi bangunan dengan pertimbangan agar mobil pemadam kebakaran dapat menjangkau seluruh sisi bangunan apartemen (lihat Gambar 5.). 
d. Sirkulasi jogging track mengelilingi bangunan

D. Analisis Pemintakatan (Penzoningan)

Pemintakatan berdasarkan sifat kegiatan, kebutuhan ruang dan peletakan Ruang Terbuka Hijau.

1. Tujuan: mintakat (zoning) berdasarkan sifat kegiatan, alur kegiatan dan kebutuhan ruang.

2. Dasar pertimbangan: analisis peruangan, analisis klimatologis tapak, dan analisis kebisingan.

3. Proses analisis: pemintakatan berdasarkan program kelompok kegiatan dan pengolahan respon terhadap klimatologis maupun kebisingan. Pada bangunan apartemen ini terdapat 6 zona yaitu zona hunian, umum, pengelola, penunjang, service dan zona hijau (lihat Gambar 6.).

E. Analisis Penerapan Desain Biophilik Dari 14 pola Desain Biophilik yang ada, maka ditentukanlah 8 pola (lihat Gambar 1.) yang akan melalu proses transformasi pada bangunan apartemen atas dasar pertimbangan kemudahan penerapan, efek terhadap psikologis dan fisik yang ditimbulkan dan kebutuhan ruang. Penerapan pola Desain Biophilik diaplikasikan pada zona hunian (lihat Gambar 7.) dan zona umum (lihat Gambar 8.).

F. Bentuk dan Tampilan Bangunan

1. Analisis Bentuk Bangunan Dasar pertimbangan dalam pemilihan bentuk bangunan adalah bentuk bangunan mengadopsi dari bentuk-bentuk alam berdasarkan penerapan salah satu pola Desain Biophilik yaitu bentuk dan patra biomorfik, penyusunan bentuk massa bangunan secara selangseling memungkinkan adanya ruang-ruang yang dapat dimanfaatkan sebagai ruang terbuka hijau sehingga penghuni dapat memiliki kemudahan akses menuju ruang terbuka hijau.
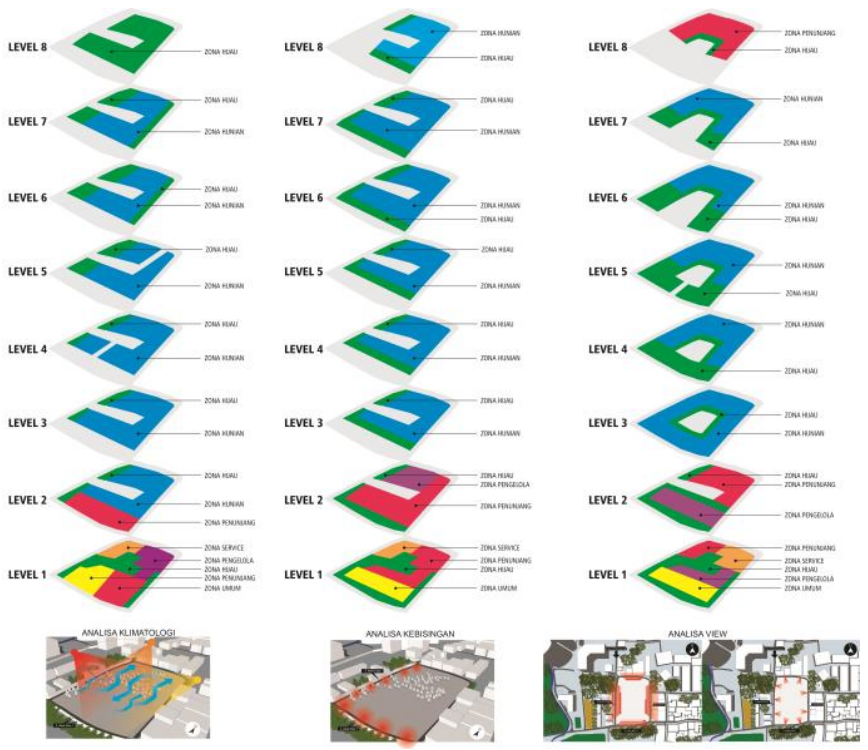

Gambar 6. Mintakat Berdasarkan Respon

Klomatologis, Kebisingan dan Pemandangan

Penerapan Pola Desain Biophilik pada Unit Hunian

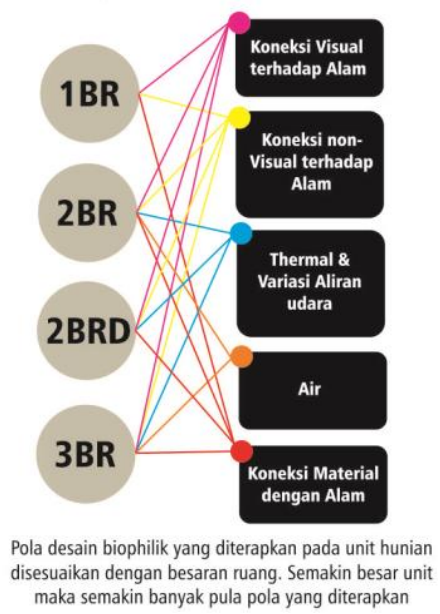

Gambar 7. Penerapan Pola Desain Biophilik pada Zona Hunian

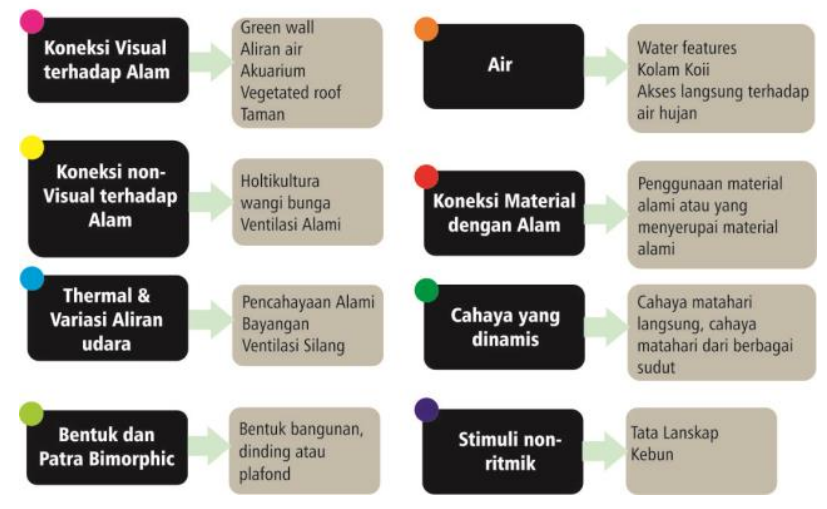

Gambar 8. Penerapan Pola Desain Biophilik pada Zona Umum 
2. Penampilan Bentuk Dasar Bangunan
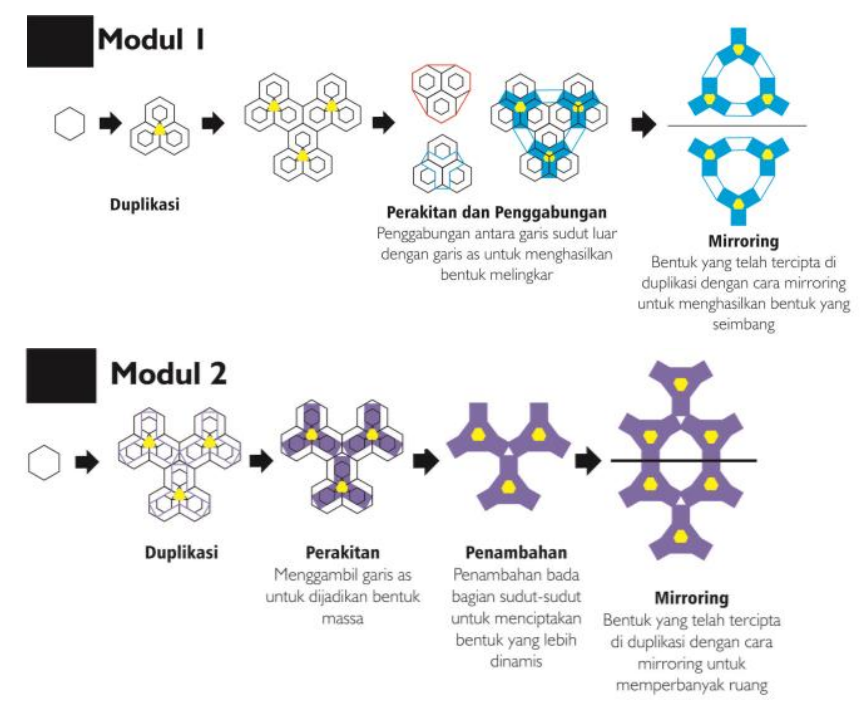

Gambar 9. Proses Transformasi

Bentuk Dasar Menjadi Modul

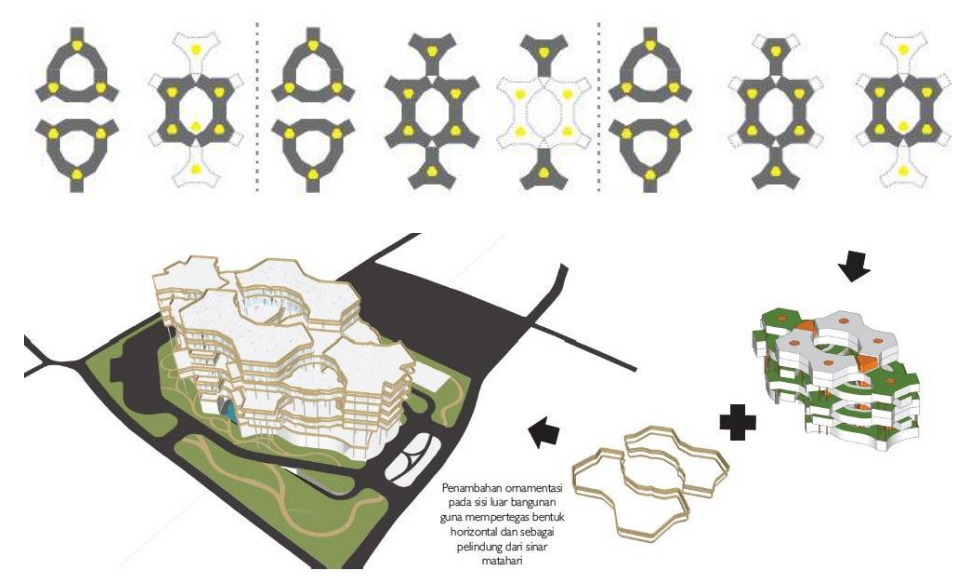

Gambar 10. Pengurangan Bentuk pada Susunan Modul Massa Bangunan dan Kronologi Bentuk Massa Bangunan

Bentuk dasar yang digunakan adalah bentuk segi enam yang diadopsi dari bentuk sarang lebah. Hal ini berdasarkan pertimbangan :

a. Dalam penyusunan, bentuk segi enam akan saling mengisi satu sama lain.

b. Fleksibilitas bentuk dan efisiensi penggunaan ruang.

c. Estetika bentuk. Bentuk segi enam kemudian mengalami transformasi menjadi 2 modul guna memudahkan dalam penyusunan massa bangunan.
Dalam proses transformasi bentuk segi enam mengalami tahap penambahan, penggabungan, perakitan, dan mirroring (lihat Gambar 9.).

3. Penyusunan modul

Modul disusun secara berselangseling. Penyusunan secara vertikal menggunakan pola 1,2-1,2,2-1,2,2 untuk menciptakan variasi bentuk antar lantai sehingga memiliki kesan dinamis (lihat Gambar 10.). Modul yang telah tersusun kemudian mengalami pengurangan pada setiap lantainya. Ruang hasil pengurangan bentuk tersebut dimanfaatkan sebagai ruang terbuka hijau.

4. Analisis Tampilan Bangunan Pola Desain Biophilik pada tampilan bangunan diterapkan pada penggunaan material alami atau material yang menyerupai alami. Material yang digunakan antara lain:

a. Batuan, diaplikasikan pada dinding dan lantai terutama pada bagian eksterior bangunan.

b. Kayu, diaplikasikan pada perabot dan lantai pada interior unit hunian.

c. Beton, warna asli beton diaplikasikan pada bagian kolom untuk menciptakan kesan alami.

d. Tegel motif tumbuhan, diaplikasikan pada bagian lantai kamar mandi.

e. Marmer, diaplikasikan pada bagian lantai baik pada unit hunian maupun pada zona umum.

f. Laminasi, pengaplikasian laminasi pada bagian plafon dengan motif biomorfik.

G. Analisa Peyediaan Ruang terbuka Hijau pada Bangunan Terdapat 2 prinsip dalam penyediaan ruang terbuka hijau pada bangunan apartemen ini, yaitu: 


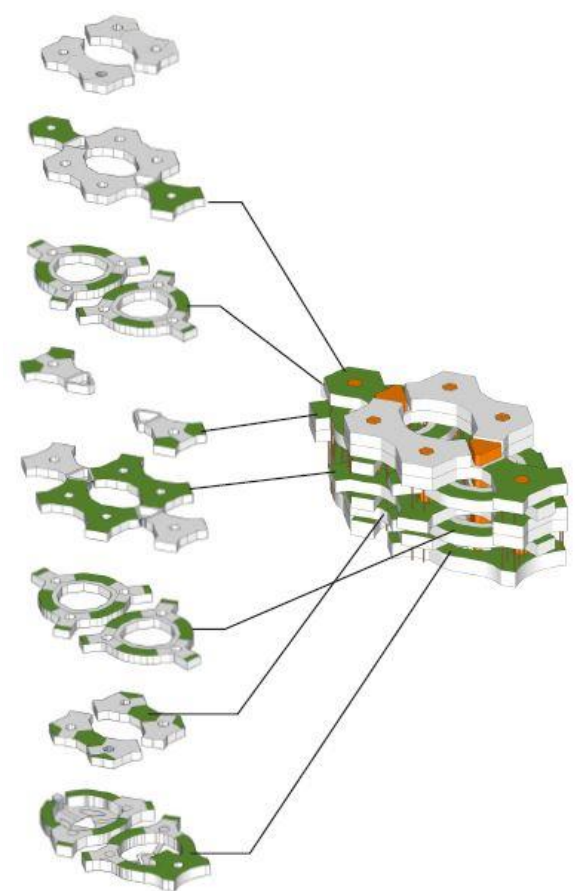

Gambar 11. Lokasi Ruang Terbuka Hijau pada Apartemen

1. RTH Dasar

$$
\begin{aligned}
\text { Luas tapak } & =27.000 \mathrm{~m}^{2} \\
\mathrm{KDH} & =45 \% \\
\text { Luas RTH } & =27.000 \mathrm{~m}^{2} \times 45 \% \\
& =12.150 \mathrm{~m}^{2}
\end{aligned}
$$

Jadi, luas ruang terbuka hijau pada bangunan apartemen memiliki luas minimal $12.250 \mathrm{~m}^{2}$

2. RTH berdasarkan Jumlah

Penduduk

Berdasarkan UU No. 26 Tahun 2007 Tentang Penataan Ruang, setiap unit lingkungan dengan jumlah penduduk 250 jiwa harus memiliki 1 Taman RT

3. Lokasi RTH

Lokasi ruang terbuka hijau pada bangunan apartemen terdapat pada bagian dasar dan tersebar pada bagian vertikal (lihat Gambar 11.). Besaran didasari oleh unit hunian apartemen yang akan difasilitasinya. Di setiap lantainya keberadaan ruang terbuka hijau memiliki luasan lebih dari $30 \%$ dari masing-masing luas lantai.
H. Struktur

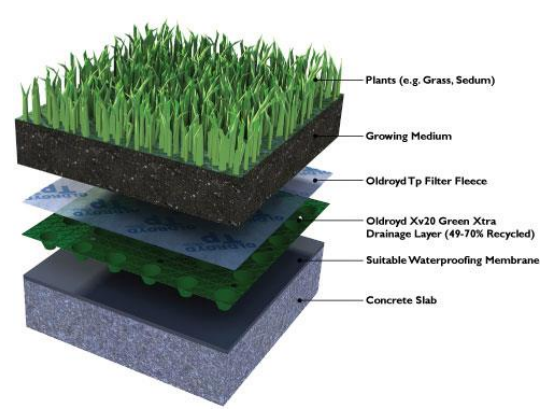

Gambar 12. Sistem Green Roof Sebagai Upper Structrure

(Sumber: www.fortcica.com)

Tujuan: sistem struktur yang sesuai dengan pembebanan.

Dasar pertimbangan: sesuai dengan kebutuhan bentuk yang direncanakan, bersifat kuat dan tahan lama, kemudahan dalam hal pemasangan saat konstruksi, dan ekonomis.

\section{Sub structure}

Penggunaan sistem tiang pancang pada bagian sub structure.

2. Super structure Super structure yang digunakan berupa kolom, balok, dinding dan plat lantai yang berbahan beton pracetak serta penggunaan sistem core wall.

3. Upper structure Upper structure yang digunakan adalah sistem atap beton bertulang dengan penambahan sistem green roof (lihat Gambar 12.) yang difungsikan sebagai ruang hijau.

\section{KESIMPULAN (KONSEP DESAIN)}

Apartemen ini dirancang sebagai sebuah hunian yang mampu mewadahi kegiatan manusia untuk memiliki koneksi terhadap alam maupun terhadap sesama manusia dengan cara meghadirkan ruang-ruang terbuka hijau pada setiap lantainya.

Kegiatan yang ada pada apartemen dikelompokkan menjadi 6 zona yaitu zona hunian, umum, pengelola, penunjang, service, dan zona ruang terbuka hijau.

Penerapan 8 pola Desain Biophilik ke dalam bangunan difokuskan pada zona hunian 
dan zona umum dimana zona tersebut merupakan zona yang paling sering digunakan.

Pada zona hunian, pola Desain Biophilik yang digunakan ada 5 pola yaitu koneksi visual terhadap alam, koneksi non-visual terhadap alam, thermal dan variasi aliran udara, air, dan koneksi material dengan alam. Pengaplikasian pola tersebut berdasarkan tingkatan dan besaran tipe unit hunian. Semakin tinggi dan semakin luas sebuah tipe unit hunian, maka semakin beragam pula jenis pola yang diterapkan di dalamnya.

Pada zona umum, pola Desain Biophilik yang digunakan ada 8 pola yaitu koneksi visual terhadap alam, koneksi non-visual terhadap alam, thermal dan variasi aliran udara, air, cahaya, stimuli non-ritmik dan koneksi material dengan alam. Pengaplikasian 8 pola ini dibedakan kembali menjadi 2 , yaitu penerapan pada zona umum dan penerapan pada massa bangunan.

Pola Desain Biophilik yang diterapkan pada zona umum yaitu koneksi visual terhadap alam, koneksi non-visual terhadap alam, dan koneksi material dengan alam. Hasil yang diharapkan dengan penerapan pola ini adalah penghuni bangunan memiliki koneksi visual maupun non-visual secara langsung sehingga penghuni dapat berinteraksi dengan alam.

Pola Desain Biophilik yang diterapkan pada massa bangunan yaitu pengolahan bentuk massa bangunan dengan menggunakan prinsip mengadopsi bentuk alam yang kemudian ditransformasikan dengan pertimbangan aliran udara, persebaran cahaya, dan penyediaan ruang hijau pada bangunan.

Penyediaan ruang terbuka hijau di setiap lantai pada unit hunian dimaksudkan untuk mewadahi kegiatan interaksi sosial sesama penghuni dan interaksi dengan alam.

Dari hasil analisa serta hasil korelasi dari beberapa data di atas, maka diperoleh hasil berupa rancangan Apartemen dengan Pendekatan Desain Biophilik di Jakarta Selatan sebagai berikut.

Nama Stadion : The Green Pile Apartment Lokasi : Jl. Lebak Bulus 1, Cilandak. Luas Lahan $\quad: \pm 20.000 \mathrm{~m}^{2}$ Luas Bangunan : $\pm 30.239 \mathrm{~m}^{2}$ Kegiatan : Bermukim Tipe Unit Hunian : 7 tipe (1 BR, 1 BR-A, 1 BR-B, 2 BR, 2BR-A, 2 BRD, 3 BR)

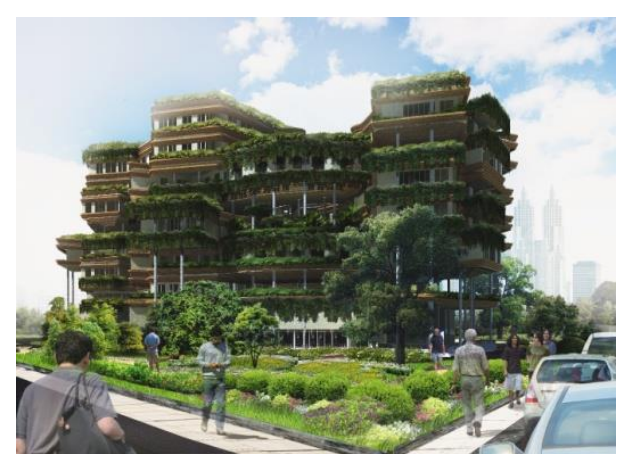

Gambar 13. Perspektif Eksterior

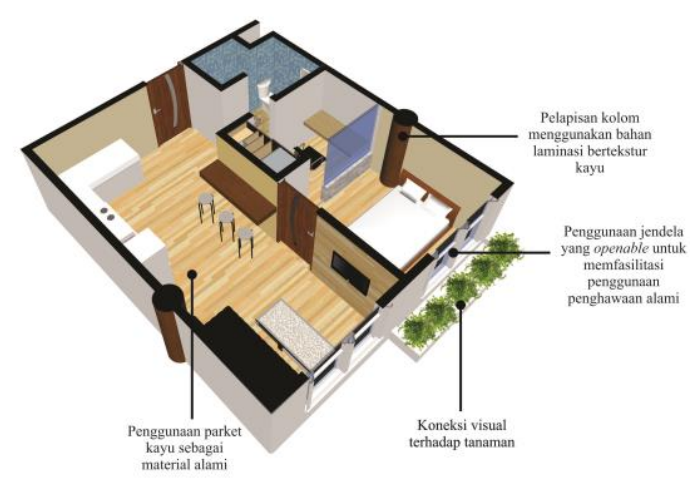

Gambar 14. Interior Tipe Hunian 1BR

\section{REFERENSI}

Browning W.D., Ryan, C.O., Clancy, J.O. 2014. 14 Patterns of Biophilic Design.

Kellert, Stephen R. 2005. Building for Life : Designing and Understanding the Human-Nature Connection.

Peratuan Menteri PU Nomor : 05/PRT/M/2008

Tentang Pedoman Penyediaan dan Pemanfaatan Ruang Terbuka Hijau di Kawasan Perkotaan www.fortcica.com 